\title{
LHRH might act as a negative autocrine regulator of proliferation of human ovarian cancer
}

\author{
Günter Emons ${ }^{1}$, Silke Weiß ${ }^{2}$, Olaf Ortmann ${ }^{2}$, Carsten Gründker ${ }^{1}$ and Klaus-Dieter Schulz ${ }^{2}$ \\ ${ }^{1}$ Departments of Gynecology and Obstetrics, Georg-August University, Robert-Koch-Street 40, D-37075, Göttingen and \\ ${ }^{2}$ Philipps University, Marburg, Germany \\ (Correspondence should be addressed to G Emons; Fax: +49-551-396585)
}

\begin{abstract}
Objective: More than $80 \%$ of human ovarian cancers express LHRH and its receptor. The proliferation of human ovarian cancer cell lines is reduced by both LHRH agonists and antagonists. This study was designed to further clarify the possible biological function of this LHRH system.

Design: As LHRH agonists and antagonists uniformly reduce proliferation of human ovarian cancer in a dose-dependent way, the effect of low concentrations of authentic LHRH was studied. In addition, longer periods of treatment (up to 9 days) were analyzed. To assess the physiological role of LHRH produced by ovarian cancer cells it was neutralized by adequate concentrations of a specific LHRH antiserum.

Methods: Human ovarian cancer cells EFO-21 and EFO-27, which express LHRH and its receptor, were incubated for 1-9 days with increasing concentrations ( $1 \mathrm{pmol} / \mathrm{l}$ to $10 \mu \mathrm{mol} / \mathrm{l})$ of authentic LHRH or with concentrations of LHRH antiserum capable of neutralizing at least $1 \mathrm{nmol} / \mathrm{l}$ LHRH. Proliferation was assessed by counting cells.

Results and conclusions: Authentic LHRH reduced time- and dose-dependently proliferation (by maximally mean \pm S.E.M. $32.7 \pm 4.4 \%$, Newman-Keuls, $P<0.001)$ of both ovarian cancer cell lines. At very low concentrations ( $1 \mathrm{pmol} / \mathrm{l})$ a marginal reduction of proliferation or no effect was observed. A mitogenic effect of authentic LHRH was never detected. Treatment of ovarian cancer cell cultures with antiserum to LHRH significantly increased (up to mean \pm s.E.M. $121.0 \pm 2.8 \%$ of controls, NewmanKeuls $P<0.001$ ) proliferation of EFO-21 and EFO-27 cells. These findings suggest that LHRH produced by human ovarian cancer cells might act as a negative autocrine regulator of proliferation.
\end{abstract}

European Journal of Endocrinology 142 665-670

\section{Introduction}

In addition to its function as a key hormone in the regulation of the pituitary-gonadal axis, luteinizing hormone-releasing hormone (LHRH), also called gonadotropin releasing hormone $(\mathrm{GnRH})$, probably affects a variety of human extrapituitary tissues (1-3). In a series of recent studies, it could be demonstrated that most ovarian cancer cell lines and primary tumors (>90\%) express LHRH immuno- and bioactivity as well as the mRNA for LHRH $(4,5)$. In addition, specific high affinity binding sites for LHRH and the expression of the mRNA for the pituitary LHRH receptor have been detected in ovarian cancer cell lines and in over $80 \%$ of biopsy specimens of these cancers $(5-8)$. The function of the expression of LHRH and its receptor is still unclear.

The proliferation of human ovarian cancer cell lines which express LHRH receptors was inhibited by both agonistic and antagonistic analogues of LHRH. These antiproliferative effects were evident at nanomolar concentrations of the LHRH analogues, suggesting that they are mediated through the LHRH receptors on the tumor cells $(9-11)$. The exact mechanism of action of this antiproliferative effect is still obscure.

The antiproliferative effects of LHRH analogues might be explained by the following hypotheses:

1. LHRH produced by tumor cells acts as autocrine stimulator. This effect will be blocked by potent LHRH agonists such as Triptorelin via downregulation of LHRH receptors and desensitization of their signaling mechanisms or by a competitive blockade of the receptors by LHRH antagonists.

2. LHRH produced by tumor cells acts as negative autocrine regulator. LHRH agonists will do the same, but more effectively than authentic LHRH.

In most cell lines LHRH agonists as well as LHRH antagonists inhibit tumor growth, like the ovarian cancer cell line EFO-21 (9-11), but in a few cell lines LHRH antagonists have no effects on cell proliferation, as in the ovarian cancer cell line EFO-27 (10). 
Therefore LHRH antagonists are not useful tools to elucidate the role of LHRH produced by the tumor cells as they behave like LHRH agonists in the majority of tumor cell lines, including ovarian cancer cell lines (10-13).

The present study was designed:

1. To assess the effects of authentic LHRH in a broad range of doses, including low concentrations (pmol/l) and over long time periods to check if under these conditions a stimulatory effect can be observed.

2. To neutralize LHRH produced by tumor cells with an anti-LHRH antiserum to assess the effects of LHRH produced by the tumor cells.

For this study ovarian cancer cell lines EFO-21 and EFO-27 were selected as a model system, because these cell lines have been shown to express LHRH and its receptor and their proliferation is significantly reduced by nanomolar concentrations of LHRH analogues $(5,10)$.

\section{Methods}

\section{Cell lines and culture conditions}

The human ovarian cell lines used were derived from a poorly differentiated serous adenocarcinoma (EFO-21) (14) or a mucinous papillary adenocarcinoma of intermediate differentiation (EFO-27) (15). The cells were cultured at $37^{\circ} \mathrm{C}$ in a water saturated atmosphere of $5 \% \mathrm{CO}_{2}$ in air. The medium used was based on Minimal Essential Medium (MEM, Eagle) and has been described in detail previously (10).

\section{Time course and dose-response proliferation experiments using authentic LHRH}

Aliquots of 2500 cells of either EFO-21 or EFO-27 cell lines were plated in multiple four-well cluster dishes of $16 \mathrm{~mm}$ diameter (Nunc, Roskilde, Denmark) in $1 \mathrm{ml}$ of medium. After $24 \mathrm{~h}$, the cells had attached to the dishes. The medium was replaced by fresh medium, and appropriate dilutions of authentic LHRH in PBS $(20 \mu \mathrm{l})$ containing BSA $(2 \mathrm{~g} / \mathrm{l})$ were added, resulting in final LHRH concentrations of $1 \mathrm{pmol} / \mathrm{l}$ to $10 \mu \mathrm{mol} / \mathrm{l}$. Controls received $20 \mu \mathrm{l}$ PBS/BSA. After 1, 3, 5, 7 and 9 days of incubation, the cells from four plates of every LHRH dose and from the respective controls were detached with $1 \mathrm{ml}$ of a solution containing $0.5 \mathrm{~g}$ trypsin (Biochrom) and $5 \mathrm{mmol}$ EDTA in 1 liter PBS/ BSA. Viable cells, determined by trypan blue exclusion, were counted in a Neubauer hemocytometer (Brandt, Wertheim, Germany). In each experiment, the number of spontaneously detached cells floating in the medium and dead (trypan blue-stained) cells was assessed (for details see ref. 10). All proliferation experiments were performed in quadruplicate and reproduced at least twice in different passages of the cell lines.

\section{Characterization of anti-LHRH antiserum}

An LHRH RIA was performed under cell culture conditions to analyze the dilution of rabbit antihuman LHRH antiserum (Sigma, Deisenhofen, Germany) sufficient to neutralize LHRH under these conditions. The antiserum was specific for LHRH and did not react with luteinizing hormone (LH), follicle-stimulating hormone (FSH) or prolactin (16). To exclude unspecific binding, rabbit normal serum was used in control experiments. A standard curve was prepared with LHRH in a serial dilution of $1: 2$ from $5000 \mathrm{pg} / \mathrm{ml}$ up to $19.5 \mathrm{pg} / \mathrm{ml}$. Rabbit anti-human LHRH antiserum was diluted in culture medium including $0.1 \%$ rabbit normal serum to final dilutions of 1:400, 1:800 and $1: 1600$. The specific activity of the labeled (3${ }^{125}$ I-iodotyrosyl ${ }^{5}$ )-LHRH (Amersham, Braunschweig, Germany) specified by the supplier was $1585 \mu \mathrm{Ci} / \mu \mathrm{g}$. After incubation under cell culture conditions $\left(37^{\circ} \mathrm{C}\right)$ for $2 \mathrm{~h}$, the ${ }^{125}$ I-LHRH-anti-LHRH antibody complex was precipitated using a donkey anti-rabbit antibody diluted in 5\% polyethylene glycol/PBS including 7\% human normal serum. The precipitated complex was measured after centrifugation by gamma counting.

Mathematical analysis of binding affinity $\left(K_{\mathrm{d}}\right)$ and binding capacity $\left(B_{\max }\right)$ of the anti-LHRH antiserum were performed using the LIGAND program, kindly provided by Drs P J Munson and D Rodbard, Laboratory of Theoretical and Physical Biology, National Institute of Child Health and Human Development, NIH, Bethesda, Maryland, USA.

\section{Standardization of anti-LHRH antiserum by rat pituitary bioassay}

A rat pituitary bioassay was performed to analyze whether or not the rabbit anti-human LHRH antiserum is able to inhibit the LHRH-induced LH secretion of pituitary cells under cell culture conditions. Primary rat pituitary cell cultures were prepared as described previously $(17,18)$ and plated in multiple four-well cluster dishes of $16 \mathrm{~mm}$ diameter (Nunc) in $1 \mathrm{ml}$ of medium. After $24 \mathrm{~h}$, the cells had attached to the dishes. The medium was replaced by fresh medium, and the cells were incubated for $3 \mathrm{~h}$ with appropriate dilutions of rabbit anti-LHRH serum, resulting in final antiserum dilutions of 1:10, 1:20, 1:50 and 1:100 in the absence or presence of $1 \mathrm{nmol} / \mathrm{l} \mathrm{LHRH}$. The LH content of the medium was determined by RIA described previously (19).

\section{Time course proliferation experiments using an antiserum against authentic LHRH}

Aliquots of 2500 cells of either EFO-21 or EFO-27 cell lines were plated and allowed to attach to the wells as described above. The medium was replaced by fresh medium, and the rabbit anti-LHRH antiserum which 



Figure 1 Dose-response experiments on cell proliferation of human ovarian cancer cell lines EFO-21 (A) and EFO-27 (B) using authentic LHRH. Cells were incubated for 7 days without (control) or with increasing LHRH concentrations. Cell number is given as a percentage of the controls (100\%). The bars represent the means \pm S.E.M. of three independent experiments, performed using different passages of the respective cell line in quadruple determinations. a, $P<0.001$ versus control; b, $P<0.01$ versus control; c, $P<0.05$ versus control.

had been tested for quantitative activity (see above) and reconstituted in $1 \mathrm{ml}$ of PBS containing BSA ( $2 \mathrm{~g} / \mathrm{l})$ was added, resulting in a 1:40 dilution. Controls received a PBS/BSA solution or PBS/BSA containing rabbit normal serum. After 1, 3, 5, 7 and 9 days of incubation, the cells were detached and counted as described above. All proliferation experiments were performed in quadruplicate and reproduced at least twice in different passages of the cell lines.

\section{Statistical analysis}

All experiments were performed at least three times in different passages of the respective cell lines. Results are expressed as percentages of respective controls and were pooled before they were tested by one-way ANOVA followed by a Newman Keuls' test for the comparison of individual groups, after a Bartlett test had shown that variances were homogeneous. Results are given as means \pm s.E.M.

\section{Results}

\section{Effects of authentic LHRH on proliferation of the human ovarian cancer cell lines}

After 1 day of treatment with authentic LHRH ( $1 \mathrm{nmol} / \mathrm{l})$ a marginal antiproliferative effect was observed $(9.6 \pm 2.7 \%$, data not shown). Longer treatment or higher concentrations of authentic LHRH resulted in an increasing antiproliferative effect. On day 3, the antiproliferative effect of $1 \mathrm{nmol} / \mathrm{l}$ authentic LHRH and higher (100 nmol/l, $10 \mu \mathrm{mol} / \mathrm{l})$ was significant (14.5 \pm $2.8 \%, \quad 16.1 \pm 2.7 \%$ and $26.7 \pm 4.3 \%$ respectively, $P<0.01)$. On day 5, even the antiproliferative effect of $10 \mathrm{pmol} / \mathrm{l}$ authentic LHRH was highly significant (16.4 $\pm 3.3 \%, P<0.001)$.

Figure 1 shows the antiproliferative effects of LHRH on day 7 . When human ovarian cancer cell lines EFO21 and EFO-27 were treated with $10 \mathrm{pmol} / \mathrm{l}$ of authentic LHRH, a significant growth inhibitory effect of $17.8 \pm 3.5 \%$ was observed. Treatment with a concentration of $10 \mu \mathrm{mol} / \mathrm{l}$ resulted in an antiproliferative effect of $32.7 \pm 4.4 \%(P<0.001)$.

A growth-promoting effect of LHRH was never observed in these experiments.

\section{Testing of anti-LHRH antiserum under cell culture conditions via LHRH RIA}

An antiserum dilution of 1:400 resulted in a maximal antiserum binding capacity of $1.16 \times 10^{-10} \mathrm{~mol} / \mathrm{l}$ and a binding affinity of $4.3 \times 10^{9} \mathrm{l} / \mathrm{mol}$. $B_{\max }$ of an $1: 800$ dilution was $4.47 \times 10^{-11} \mathrm{~mol} / \mathrm{l}$, while the $K_{\mathrm{d}}$ was similar to that above $\left(K_{\mathrm{d}}=5.48 \times 10^{9} \mathrm{l} / \mathrm{mol}\right)$. An $1: 1600$ dilution resulted again in an approximately $50 \%$ decrease of $B_{\max }\left(2.8 \times 10^{-11}\right)$, while the $K_{\mathrm{d}}$ was similar to that found at the other antiserum dilutions $\left(K_{\mathrm{d}}=4.13 \times 10^{9} \mathrm{l} / \mathrm{mol}\right)$.

\section{Characterization of anti-LHRH antiserum}

The neutralizing effect of anti-LHRH antiserum on exogenous LHRH action in rat pituitary cell culture, shown as decreased LH secretion, was demonstrated (data not shown). LHRH at $1 \mathrm{nmol} / \mathrm{l}$ induced a threefold increase of LH secretion which was significantly reduced by several antiserum dilutions. In a dilution of 1:50, LHRH-induced LH secretion was reduced to basal levels (LH basal level: $9.0 \pm 0.1 \mathrm{ng} / \mathrm{ml}$ per $3 \mathrm{~h}$; antiserum reduced level: $10.7 \pm 0.3 \mathrm{ng} / \mathrm{ml}$ per $3 \mathrm{~h})$. An antiserum dilution of 1:10 reduced the LH secretion induced by $1 \mathrm{nmol} / \mathrm{l} \mathrm{LHRH}$ to $5.1 \pm 1.1 \%$.

In proliferation experiments, the anti-LHRH antiserum was used in a 1:40 dilution with a calculated neutralizing capacity of $10 \mu \mathrm{mol} / \mathrm{l} \mathrm{LHRH}$, which ought to be high enough to eliminate LHRH produced by the tumor cells (5). 


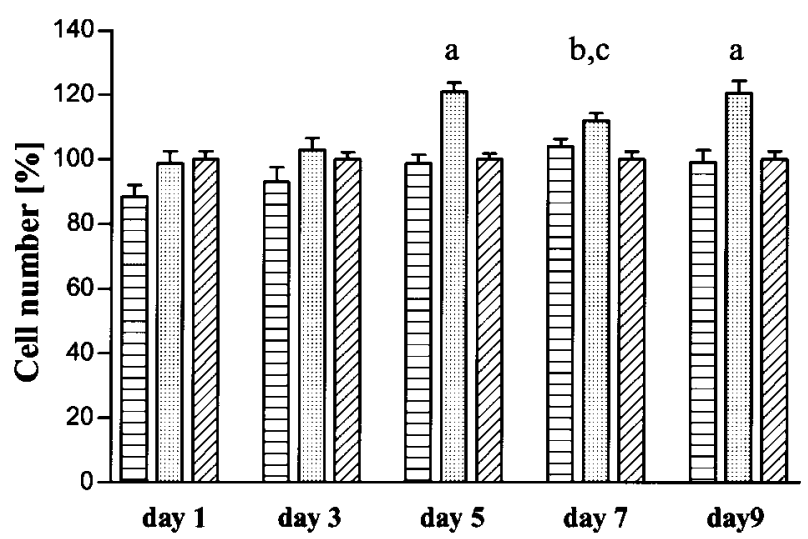

Figure 2 Time-course experiments of proliferation of the human ovarian cancer cell line EFO-21 in the presence of an antiserum against authentic LHRH. Cells were incubated with normal rabbit serum (left bars) or with anti-LHRH antiserum (middle bars) or without rabbit serum (right bars). Cell number is given as a percentage of the controls (100\%). The bars represent the means \pm S.E.M. of three independent experiments, carried out using different passages of the cell line in quadruple determinations. $a$, $P<0.001$ versus control and normal rabbit serum; b, $P<0.01$ versus control; c, $P<0.05$ versus normal rabbit serum.

\section{Effects of anti-LHRH antiserum on cell proliferation}

When EFO-21 and EFO-27 human ovarian cancer cell lines were incubated with an 1:40 dilution of the antiLHRH antiserum, an increased proliferation was observed (Figs 2 and 3). On day 3 of antiserum treatment, a nonsignificant effect $(103.6 \pm 3.7 \%)$ as compared with controls $(100 \%)$ was observed in the cell line EFO-21 which proliferates slowly (Fig. 2). On day 5 the growthpromoting effects of the LHRH antiserum were highly significant $(121.0 \pm 2.8 \%)$ in comparison with control cultures treated with PBS in the absence or presence of normal rabbit serum $(P<0.001)$. Normal rabbit serum had no mitogenic effect. Cell death in the different experiments using anti-LHRH antiserum or PBS with or without normal rabbit serum was in the same range (5\%).

In the quickly proliferating cell line EFO-27 (Fig. 3) anti-LHRH antiserum induced growth acceleration was already observed on day 1 of treatment (119 $\pm 2.7 \%)$. This effect was highly significant in comparison with control cultures treated with PBS in the absence or presence of normal rabbit serum $(P<0.001)$. On day 7 of culture the mitogenic effect of LHRH antiserum vanished due to confluence of cells in both control and experimental cultures. Cell death in all experiments including the controls was in the same range $(5 \%)$. A growth-promoting effect of normal rabbit serum was never observed in these experiments.

\section{Discussion}

In view of the apparent similarity of LHRH receptors in ovarian cancers to those in the pituitary, it seems

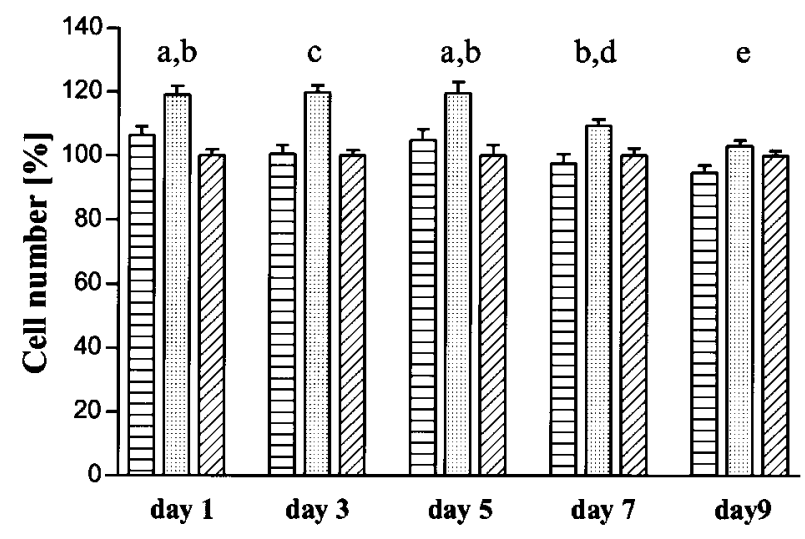

Figure 3 Time-course experiments of proliferation of the human ovarian cancer cell line EFO-27 in the presence of an antiserum against authentic LHRH. Cells were incubated with normal rabbit serum (left bars) or with anti-LHRH antiserum (middle bars) or without rabbit serum (right bars). Cell number is given as a percentage of the controls (100\%). The bars represent the means \pm S.E.M. of three independent experiments, carried out using different passages of the cell line in quadruple determination. a, $P<0.001$ versus control; $b, P<0.001$ versus control and normal rabbit serum; c, $P<0.01$ versus normal rabbit serum; d, $P<0.05$ versus control; e, $P<0.05$ versus normal rabbit serum.

reasonable to speculate that also LHRH signal transduction pathways in the tumors might be the same as those operating in pituitary gonadotrophs (20). Our findings, however, suggest that the classical LHRH receptor signal transduction pathways, known to operate in pituitary gonadotrophs, are not involved in the mediation of antiproliferative effects of LHRH analogues in ovarian cancer cells (21). LHRH analogues interfere with the mitogenic signal transduction pathway of growth factor receptors and related oncogene products associated with tyrosine kinase activity (13). Our group performed extensive studies in human ovarian cancer cell lines (EFO-21 and EFO-27). These cell lines express high affinity LHRH receptors as well as bioactive LHRH, and their proliferation is inhibited by LHRH analogues $(5,10,12)$ demonstrating the existence of several components essential for a local regulatory system based on LHRH. In prostatic cancer cells, LHRH agonists inhibit proliferation by interfering with some of the cellular mechanisms mediating the stimulatory action of the epidermal growth factor (EGF) and the insulinlike growth factor (IGF) system $(22,23)$. Dondi et al. (24) found that LHRH agonists exert significant and dose-dependent antiproliferative action on DU 145 prostate cancer cells. Both LHRH and its receptor are expressed in this cell line, indicating that an autocrine/ paracrine LHRH loop is present in androgen-independent prostate cancer cells, and may participate in the regulation of tumor growth. Recent observations in prostate cancer suggest that the LHRH receptor seems to be coupled to the G $\alpha(\mathrm{i})$-cAMP signal transduction pathway, rather than to the $\mathrm{G} \alpha(\mathrm{q} / 11)$-phospholipase C 
signaling system (25). In ovarian cancer cells cAMP is not involved in LHRH signaling (21). Furthermore, the precise mechanism through which LHRH and its analogues reduce cancer cell proliferation is still unknown. Thompson et al. (9) suggested that an increase of cells in the G0/G1 phase of the cell cycle and a respective reduction of the $\mathrm{S}$-phase fraction might explain this phenomena. Imai et al. (26) recently proposed that LHRH might activate the pro-apoptotic system in ovarian cancer cells. In our labs, LHRH and both agonistic and antagonistic analogues did not induce apoptosis in EFO-21 and EFO-27 cells (data not shown).

One prerequisite to accept an LHRH-based autocrine system is to detect LHRH bioactivity in the culture media of ovarian cancer cell lines. Production of LHRH by EFO-21 and EFO-27 ovarian cancer cells could be clearly demonstrated in earlier experiments (5). Despite several efforts, however, we were not able to detect LHRH activity in the media conditioned by EFO-21 and EFO-27 using a highly sensitive LHRH RIA (sensitivity: $15 \mathrm{fmol} / \mathrm{ml}$; data not published). Similarly, Ohno et al. (4) found LHRH activity in extracts of the SK-OV-3 ovarian cancer cell line but not in conditioned media.

Our data demonstrate that $\mathrm{pmol} / \mathrm{l}$ concentrations (equivalent to $1 \mathrm{fmol} / \mathrm{ml}$ ) of authentic LHRH had either no effects or antiproliferative effects. No mitogenic effect of authentic LHRH on human ovarian cancer cell lines was observed. It could be speculated that even lower LHRH concentrations (fmol/l) might have stimulatory effects on cell growth as postulated by Qayum et al. (27) for prostatic cancer cell lines. As LHRH receptor binding affinity $\left(K_{\mathrm{d}}\right)$, however, is in the range of a few nmol/l, this seems to be not very reasonable. To rule out the possibility that fmol/l concentrations of LHRH secreted by the tumor cells stimulate their proliferation, the experiments with anti-LHRH antiserum were performed. If Qayum's (27) hypothesis was true, neutralization of LHRH secreted by the tumor cells should result in growth inhibition. Instead of that we observed a significant growth stimulation in both cell lines. These results are rather in agreement with our theory that LHRH produced by the tumor cells reduces their proliferation. The phenomenon that LHRH is clearly detectable in cell extracts but not in conditioned medium remains an area of speculation. It might be possible that LHRH is secreted by tumor cells in a pulsatile fashion and is rapidly degraded in the medium. Alternatively, an immediate re-uptake of LHRH by the tumor cells might prevent its detection in conditioned media. Assuming a pulsatile release of LHRH by the tumor cells, leading to short-lived fmol/l concentrations of the decapeptide in the medium, it might be speculated that continuous treatment with even pmol/l concentrations as performed by us might downregulate LHRH receptors or desensitize the system and thus blunt the physiologic mitogenic effect of pulsatile LHRH release by the tumor cells. However, our data obtained with antiLHRH antiserum clearly argue against this speculation.
In conclusion, the data obtained with low concentrations of LHRH and those obtained with anti-LHRH antiserum rather support the concept that LHRH produced by the tumor cells has an inhibitory effect on their proliferation. The exploitation of this negative autocrine LHRH system might open new therapeutic options in cancer therapy.

\section{Acknowledgments}

This study was supported by the Deutsche Forschungsgemeinschaft (SFB 215/B10).

\section{References}

1 Schally AV. Hypothalamic hormones from neuroendocrinology to cancer therapy. Anticancer Drugs 19945 115-130.

2 Emons G \& Schally AV. The use of luteinizing hormone-releasing hormone agonists and antagonists in gynecological cancers. Human Reproduction $199491364-1379$.

3 Harris N, Dutlow C, Eidne K, Dong KW, Roberts J \& Millar RP. Gonadotropin-releasing hormone gene expression in MDA-MB-231 and ZR-75-1 breast carcinoma cell lines. Cancer Research 1991 $512577-2581$.

4 Ohno T, Imai A, Furui T, Takahashi K \& Tamaya T. Presence of gonadotropin-releasing hormone and its messenger ribonucleic acid in human ovarian epithelial carcinoma. American Journal of Obstetrics and Gynecology 1993169 605-610.

5 Irmer G, Bürger C, Müller R, Ortmann O, Peter U, Kakar SS et al. Expression of the mRNAs for luteinizing hormone-releasing hormone (LHRH) and its receptor in human ovarian epithelial carcinoma. Cancer Research 199555 817-822.

6 Emons G, Pahwa GS, Brack C, Sturm R, Oberheuser F \& Knuppen R. Gonadotropin releasing hormone binding sites in human epithelial ovarian carcinomata. European Journal of Clinical Oncology 198925 215-221.

7 Imai A, Ohno T, Ohsuye K \& Tamaya T. Expression of gonadotropinreleasing hormone receptor in human epithelial ovarian carcinoma. Annals of Clinical Biochemistry 199431 550-555.

8 Srkalovic G, Schally AV, Wittliff JL, Day TG Jr \& Jenison EL. Presence and characteristics of receptors for [D-Trp6]luteinizing hormone releasing hormone and epidermal growth factor in human ovarian cancer. International Journal of Oncology 199812 489-498.

9 Thompson MA, Adelson MD \& Kaufman LM. Lupron retards proliferation of ovarian epithelial tumor cells cultured in serumfree medium. Journal of Clinical Endocrinology and Metabolism 199172 1036-1041.

10 Emons G, Ortmann O, Becker M, Irmer G, Springer B, Laun R et al. High affinity binding sites and direct antiproliferative effects of LHRH analogues in human ovarian cancer cell lines. Cancer Research 199353 5439-5446.

11 Yano T, Pinski J, Radulovic S \& Schally AV. Inhibition of human epithelial ovarian cancer cell growth in vitro by agonistic and antagonistic analogues of luteinizing hormone-releasing hormone. Proceedings of the National Academy of Sciences of the USA 199491 1701-1705.

12 Emons G, Schröder B, Ortmann O, Westphalen S, Schulz KD \& Schally AV. High affinity binding and direct antiproliferative effects of luteinizing hormone-releasing hormone analogs in human endometrial cancer cell lines. Journal of Clinical Endocrinology and Metabolism 199377 1458-1464.

13 Emons G, Ortmann O, Schulz KD \& Schally AV. Growth-inhibitory actions of luteinizing hormone releasing hormone on tumor cells. Trends in Endocrinology and Metabolism 19978 355-362.

14 Simon WE, Albrecht M, Hänsel M, Dietel M \& Hölzel F. Cell lines derived from human ovarian carcinomas: growth stimulation by 
gonadotropic and steroid hormones. Journal of the National Cancer Institute 198370 839-845.

15 Kunzmann R \& Hölzel F. Kariotype alterations in human ovarian carcinoma cells during long-term cultivation and nude mouse passage. Cancer Genetics and Cytogenetics 198728 102-112.

16 Koch Y, Wilchek M, Fridkin M, Chobsieng P, Zor U \& Lindner HR. Production and characterization of an antiserum to synthetic gonadotropin-releasing hormone. Biochemical and Biophysical Research Communications 197355 616-622.

17 Emons G, Hoffmann HG, Brack C, Ortmann O, Sturm R, Ball P et al. Modulation of gonadotropin-releasing hormone receptor concentration in cultured female rat pituitary cells by estradiol treatment. Journal of Steroid Biochemistry and Molecular Biology $198831751-756$

18 Hyde CL, Childs G, Wahl LM, Naor Z \& Catt KJ. Preparation of gonadotropin-enriched cell populations from adult rat anterior pituitary cells by centrifugal elutriation. Endocrinology 1982111 1421-1423.

19 Ortmann O, Wiese H, Knuppen R \& Emons G. Acute facilitory action of progesterone on gonadotropin secretion of perifused rat pituitary cells. Acta Endocrinologica 1989121 426-434.

20 Stojilkovic SS \& Catt KJ. Expression and signal transduction pathway of gonadotropin releasing hormone receptors. Recent Progress in Hormone Research 199530 161-205.

21 Emons G, Müller V, Ortmann O, Grossmann G, Trautner U, von Stuckrad B et al. Luteinizing hormone-releasing hormone agonist triptorelin antagonizes signal transduction and mitogenic activity of epidermal growth factor in human ovarian and endometrial cancer cell lines. International Journal of Oncology 19969 1129-1137.

22 Moretti RM, Montagnani-Marelli M, Dondi D, Poletti A, Martini L, Motta $\mathrm{M}$ et al. Luteinizing hormone-releasing hormone agonists interfere with the stimulatory actions of epidermal growth factor in human prostatic cancer cell lines, LNCaP and DU 145. Journal of Clinical Endocrinology and Metabolism 199681 3930-3937.

23 Montagnani-Marelli M, Moretti RM, Dondi D, Motta M \& Limonta P. Luteinizing hormone-releasing hormone agonists interfere with mitogenic activity of the insulin-like growth factor system in androgen-independent prostate cancer cells. Endocrinology 1999140 329-334.

24 Dondi D, Limonta P, Moretti RM, Marelli MM, Garattini E \& Motta M. Antiproliferative effects of luteinizing hormone-releasing hormone (LHRH) agonists on human androgen-independent prostate cancer cell line DU 145: evidence for an autocrineinhibitory LHRH loop. Cancer Research 199454 4091-4095.

25 Limonta P, Moretti RM, Montagnani-Marelli M, Dondi D, Parenti M \& Motta M. The luteinizing hormone-releasing hormone receptor in human prostate cancer cells: messenger ribonucleic acid expression, molecular size, and signal transduction pathway. Endocrinology 1999140 5250-5256.

26 Imai A, Takagi A, Horibe S, Takagi H \& Tamaya T. Evidence for tight coupling of gonadotropin-releasing hormone receptor to stimulate Fas ligand expression in reproductive tumors: possible mechanism for hormonal control of apoptotic cell death. Journal of Clinical Endocrinology and Metabolism 199883 127-131.

27 Qayum A, Gullick WJ \& Waxman J. Gonadotropin-releasing hormone: physiological significance and relevance to cancer. Progress in Growth Factor Research 19913 115-130.

Received 20 September 1999

Accepted 9 February 2000 